\title{
The Role Of Negative Information In Dissolving Consumer Identification With Companies
}

Susan G. Rozensher, Iona College, USA

P. Everett Fergenson, Iona College, USA

\begin{abstract}
A benefit of strong consumer identification with a company has been hypothesized to be consumers' greater resilience to negative information about the company. The positive consequences of strong consumer-company identification, however, have been proposed to have their limits, or "zone of tolerance". The present study extended and tested the "zone of tolerance" hypothesis by measuring reactions of company-identified consumers when confronted with negative information that challenged their strong identification with the company.
\end{abstract}

Keywords: Customer loyalty, Negative information, Customer-company identification

\section{INTRODUCTION}

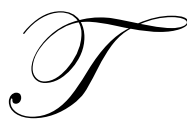

he benefits of customer loyalty have been well established as both crucial and wide-ranging. They include the lower cost of customer retention when compared with the expense of new customer acquisition, the lower costs associated with serving repeat purchasers, and increased revenues due to the willingness of loyal customers to pay premium prices, buy more, and provide new referrals through positive word-of-mouth. All of these factors lead to enhanced profitability (Reichheld, 1993; Reichheld and Sasser, 1990; Reicheld and Teal, 1996; Zeithaml, 2000; Zeithaml et al, 2001; DeWulf et al, 2001; Shankar, Smith, and Rangaswamy, 2003).

An outgrowth of this acceptance of customer loyalty's key role has been the extensive focus in both managerial and academic circles on customer relationship marketing; that is, organizational efforts to maintain customer loyalty and stimulate repeat purchase over time. Relationship marketing efforts have spawned a proliferation of so-called loyalty programs designed to enhance customer retention and also raise the purchasing levels of customers by offering rewards of various types.

Numerous studies have been conducted to evaluate the relative effectiveness of loyalty programs in a practical attempt to identify the most advantageous methods and principles of rewarding the customer. The results have been inconsistent (Uncles, Dowling and Hammond, 2003; Lewis, 2004; Bellizzi and Bristol, 2004; Sharp and Sharp, 1997; Dowling and Uncles, 1997), leaving open the question of whether reward programs indeed generate loyalty and increase customer retention. Indeed, some attempts have been made to identify other forms of intervention that might improve customer loyalty (Divett, Crittenden, and Henderson, 2003).

While marketing firms, as well as academic researchers, have dedicated much attention to the cultivation of consumer-company relationships, the subject of relationship dissolution has been largely neglected by comparison (Perrin-Martinenq, 2004; Rees and Gardner, 2003; Rowley and Dawes, 2000). The current study is an effort to address this neglect by investigating certain factors that may contribute to the dissolution of strong consumercompany (C-C) relationships. (It should be pointed out that the term "company" is used here in its broadest sense, to include both for-profit and nonprofit organizations that make product offerings - e.g. goods, services, information, and ideas - to satisfy consumers' needs and wants.) 
In order to understand both the bonds that underpin the strong relationship of a consumer with a company and the threats that can dissolve such a relationship, we can draw upon theories of social identity (Brewer, 1991; Tajfel and Turner, 1985) and organizational identification (Bergami and Bagozzi, 2000; Dutton, Dukerich, and Harquail, 1994; Mael and Ashforth, 1992; Scott and Lane, 2000). These theories have been applied to the consumer arena in a proposed conceptual framework that articulates both the key determinants of identification with a company and the consequences of such identification (Bhattacharya and Sen, 2003; Ahearne, Bhattacharya, \& Gruen, 2005). The authors argue that a strong consumer-company (C-C) relationship is the product of consumers' identification with the company, which in turn derives from the relationship's ability to help satisfy some of the consumers' crucial self-definitional needs. In the process of constructing their identities, consumers self-categorize themselves in part by identifying with a company that provides a good match with their own defining characteristics such as personality, values, and demographics (Ashford and Mael, 1989; Dutton, Dukerich and Harquail, 1994; Pratt, 1998).

Consumers identifying with a company feel a sense of connectedness or belonging to an organization and define themselves partly in terms of that organization (Mael and Ashforth, 1992). Their self-definitional needs which include the need for self-enhancement (satisfied in part by identifying with prestigious companies and organizations); the need for self-distinctiveness (satisfied in part by identifying with companies or organizations that are distinctive and unique on dimensions that the consumer values), and the need for self-continuity (the need to express more completely their particular traits and values; Markus and Wurf, 1987; Pratt, 1998) - are satisfied, to some degree, through this relationship with the company.

Bhattacharya and Sen (2003) contend that the notion of consumer-company identification is the "primary psychological substrate for the kind of deep, committed and meaningful relationships that marketers are increasingly seeking to build with their customers". In today's competitive marketplace, companies that have succeeded in building deep, meaningful, and long-term relationships with their customers have achieved the ultimate payoff consumers who are not only thoroughly loyal to the company but actually champion the company by spreading enthusiastic word-of-mouth. (These devoted consumers are sometimes dubbed "customer evangelists", as described by McConnell and Huba (2003).)

In addition to the benefits of strong company loyalty and enthusiastic word-of-mouth promotion, an added benefit of strong consumer-company identification has been hypothesized to be consumers' greater resilience to negative information about the company "within a zone of tolerance" (Bhattacharya and Sen, 2003). In other words, the higher the level of consumer-company identification, the more likely consumers would be to downplay disappointments with the company and its products and to overlook relatively minor negative information about the company. One empirical study offering support for this contention found that "attitudinally loyal" customers are much less susceptible to negative information about a brand than non-loyal customers (Ahluwalia et al, 1999). The results of a study by Bergami and Bagozzi (2000) also lend some credence to this proposal by showing that identification with an organization causes people to treat the organization with altruism, courtesy, and sportsmanship. In a similar vein, Dick and Basu (1994) evaluated the role of customer loyalty in making customers more resistant to counter-persuasion.

The positive consequences of strong consumer-company identification, however, have been proposed to have their limits. That is, according to Bhattacharya and Sen's hypothesis (2003), "beyond a zone of tolerance, the higher the level of consumer-company identification, the stronger and more permanent are consumers' reactions to negative information about the company". In other words, negative information of significant magnitude would be expected to damage severely the consumer's identification with the company. Furthermore, the authors hypothesized that the reaction of consumers would be especially severe in cases where the negative information is perceived as a betrayal of identity authenticity and trust (for instance, when an environmentally activist company is exposed for polluting a lake). The company-identified consumer would be more likely to "retaliate" by perhaps refusing to purchase the company's products or by engaging in negative word-of-mouth. In the case of nonprofit organizations, retaliation could amount to loyal members refusing to renew their membership and/or support for the organization. 
Several factors leading to the dissolution of a loyal relationship have been proposed in the marketing literature that can be related to the conceptual framework articulated by Bhattacharya and Sen (2003), and in particular, to the concept of "beyond the zone of tolerance". Specifically, one determinant of relationship dissolution has been identified as "sudden death" (Fajer and Schouten, 1995), i.e. dissolution caused by the revelation of new, surprising and negative information about a partner, such as exposure of corporate malfeasance. In a similar line of reasoning, Fournier (1998) has proposed two models of dissolution: an entropy model and a stress model. According to the entropy model, relationships gradually fade away because they are not actively maintained. However, in the stress model - as in "beyond the zone of tolerance" and "sudden death" - relationships can dissolve due to stress from a variety of factors, among them "dyadic/relational stress", which refers to the breaking of unwritten relationship rules, a breakdown of trust, or a failure to keep a promise.

Based on these models of consumer-company identification and with particular reference to relationship dissolution, we designed a study to test the "zone of tolerance" hypothesis by measuring reactions of companyidentified consumers when confronted with company-related negative information that could challenge their strong identification with the company.

\section{METHODOLOGY}

\section{Sample}

We selected study participants from the population of members of a nonprofit organization, in this case, a public radio station in a large metropolitan area, to ensure that the sample consisted of consumers who were highly identified with the company. The radio station members can be considered strongly identified with the organization since they had voluntarily chosen to pay the station membership fee when, in fact, they could have accessed the radio station's broadcasts without paying. In the terminology of the marketing literature that focuses on loyalty in specific, these station members would be considered "behaviorally loyal" on the basis of their act of paying the membership fee voluntarily (Ball, Coelho, and Machas, 2003; Oliver, 1997; Zeithaml, 2000; Chaudhuri and Holbrook, 2001). Similarly, it has been argued that membership in nonprofit organizations (such as theatres, museums, and universities) is an appropriate basis for studying company identification (Bhattacharya, Rao, and Glynn, 1995).

Participants were selected from a sampling frame provided by the public radio station's members through the use of a probabilistic sampling technique known as systematic sampling. Participants were contacted by telephone, and were interviewed by MBA students from a marketing research class who read from a scripted survey. A total of 148 respondents participated in the study, $48 \%$ male and 52\% female. The number of years of membership was recorded for each respondent, to be used in a test of one of our hypotheses. The sample proved to be a highly educated one, with over $80 \%$ of respondents having earned a college degree (similar to the membership of many nonprofit cultural organizations, as reported in Bhattacharya, Rao, and Glynn (1995) and DiMaggio and Ostrower (1990)).

\section{Baseline Measures}

Several measures were first taken to establish baseline levels of the members' satisfaction with the radio station, and of their intention to renew their membership under current conditions. To establish the sample members' level of satisfaction, two separate measures were taken. One measure asked members to rate their overall level of satisfaction with the radio station's treatment of its members on a five point scale, ranging from "very satisfied" to "very dissatisfied". The other satisfaction measure asked respondents to rate their level of satisfaction with the way the radio station has used its revenues from membership fees, again using a five-point satisfaction scale.

In order to establish a baseline measure to be used for comparison purposes, the respondents were asked to rate their likelihood of renewing their radio station membership on a five point scale that ranged from "very likely" to "very unlikely". The results of this measure would be used later as a basis for comparison with the members' reported likelihood to renew their membership under the hypothetical situations presented to them. 


\section{HYPOTHESES}

\section{Negative Information About Shared Values}

We presented our study participants with two hypothetical situations, both of which contained companyrelated negative information as follows. In the first scenario, consumers were asked for their reaction to a situation in which a company, with which they were known to identify strongly, entered into a financial arrangement with another company said to behave ethically but support causes not in agreement with the consumers' values. We hypothesized that this scenario, which represented a significant loss of shared values with the identified company and a concomitant loss of satisfaction of the consumers' self-definitional needs, would lead the study participants to experience a rather negative reaction and to report a significantly increased likelihood to dissolve their relationship with the company. In essence, we expected the company's hypothetical behavior to register with consumers as going "beyond the zone of tolerance" and to be perceived as a betrayal of identity authenticity and trust (Bhattacharya and Sen 2003).

\section{Negative Information About Ethical Integrity}

The second scenario was designed to represent a more extreme case of a betrayal of identity authenticity and trust. Study participants were asked for their reactions to a situation in which the same company with which they were known to identify strongly had entered into a financial arrangement with a company that had engaged in some unethical practices. We hypothesized that, in accordance with the Bhattacharya and Sen (2003) framework, consumers would be even more likely than in the first scenario to report a significantly increased intention to dissolve their relationship with the company. We expected that this scenario, in which the company's ethical integrity had been compromised, would be perceived as a clear breach of the "zone of tolerance" (Bhattacharya and Sen, 2003) or a cause for "sudden death" (according to Fajer and Schouten, 1995) and "dyadic/relationship stress" (according to Fournier 1998).

For both scenarios, the participants' likelihood to renew their membership was measured on a 5-point scale that ranged from "very likely" to "very unlikely". This was the same scale that was used to obtain a baseline measure of respondents' likelihood to renew their membership under current conditions.

\section{Role Of Relationship Longevity}

For all study participants, we recorded the number of years they had been members of the radio station. We hypothesized that under "normal" circumstances, the longer a person had identified with a company, the stronger their identification with it would be. We based this expectation on some previous studies of identification with organizations that demonstrated a significant, positive relationship between the length of time a person is actively involved in an organization and the strength of their identification with it (Mael and Ashforth, 1992; Bhattacharya, Rao and Glynn, 1995). (It should be noted that the opposite effect has also been reported, although in a setting dissimilar to the one used here (Bendall-Lyon and Powers, 2002)). Strong attitudes have also been shown to remain stable over time, as compared with ambivalent attitudes (Krosnick and Petty 1995).

In spite of the expected positive relationship between longevity of identification and strength of identification, we hypothesized that in the case of exposure to negative company-related information that went "beyond the zone of tolerance" and represented a betrayal of identity authenticity and trust, longer-term identification with the company would not mitigate consumers' likelihood to dissolve their relationship with it. In other words, we expected that consumers' likelihood to dissolve their relationship with the company in each of the proposed scenarios - diminishment of shared values and breach of ethical integrity - would not be moderated by virtue of a longer-term relationship. In this sense, we mean to propose and test an extension of the Bhattacharya and Sen (2003) conceptual framework by investigating the impact of relationship duration on the reactions of strongly identified consumers to negative identity-related information about a company that goes "beyond the zone of tolerance". 


\section{RESULTS}

The results of the two different measures of the radio station members' satisfaction concurred in finding the members to be highly satisfied. In response to the question asking for their level of satisfaction with the way the radio station has treated its members, over 75\% said they were either "very satisfied" or "satisfied" (the top two levels of satisfaction on a five-point scale). This high degree of satisfaction is a strong indication of "attitudinal loyalty" (Ball, Coelho, and Machas 2003; Oliver, 1997; Zeithaml, 2000; Chaudhuri and Holbrook, 2001; Bennett and Rundle-Tiele, 2004). Similarly, when asked to rate the way the station has used its revenues from membership fees, over $80 \%$ stated they were either "very satisfied" or "satisfied" on a five-point satisfaction scale. Taken together, these results suggest a highly satisfied group of customers.

As another baseline measure, we asked respondents to rate their likelihood to renew their yearly membership. The results revealed an extremely high level of intention to renew, with a mean of 4.36 on a five point scale. The members thus demonstrated a high level of what is often characterized as "attitudinal loyalty" in this measure of their intentions (Ball, Coelho, and Machas, 2003; Oliver, 1997). These measures are also consistent with the description of the sample as highly identified with the company in question (the public radio station). Such results, together with the responses to the two measures regarding customer satisfaction, suggest clearly that the radio station membership is not only exceedingly satisfied but also plans to continue its relationship with the station into the future.

After establishing a baseline for the measure of "likelihood to renew their membership", we posed two hypothetical situations (as described in the methodology section) that were hypothesized to go "beyond the zone of tolerance" to see how customer-company identification would be affected. For the "loss of shared values" situation (an ethical company that becomes an underwriter of the radio station is a supporter of a cause with which the member does not agree), members' reported "likelihood to renew" dropped drastically from the baseline mean of 4.36 to 3.30. Indeed, this drop from the baseline measure proved to be statistically significant $(t=8.005, \mathrm{p}<.001)$.

The other scenario was designed to test reaction to a perceived compromising of the organization's ethical integrity. This would constitute negative identity-related information that would amount to a severe betrayal of identity authenticity and trust. In that case, we asked the respondents to use a five-point scale to rate their likelihood to renew their membership if a company or organization that has engaged in some unethical practices were to become a financial supporter of the radio station. The likelihood to renew dropped precipitously from the baseline mean of 4.36 to 2.76. This plunge from baseline levels of likelihood to renew also proved to be highly significant ( $t$ $=11.431, \mathrm{p}<.001)$. Finally, when the levels of likelihood to renew under the two hypothetical circumstances were compared with each other, the differences were also found to be highly significant $(\mathrm{t}=4.646, \mathrm{p}<.001)$.

To test our hypothesis that longer-term members of the radio station would be more highly identified with the station than newer members, members were first classified as either "veteran members", who had subscribed to the station for two or more years, or "new members", who belonged for less than two years. Identification with the station was operationalized as members' initial likelihood to renew their membership under current conditions, reported on the five-point likelihood scale described in the methodology section. The results showed that indeed veteran members reported a significantly greater likelihood to renew their memberships than the newer members in our sample $(\mathrm{p}<.05)$ at the outset of this study (i.e. under current conditions), thus confirming our hypothesis.

We also tested our hypothesis that a longer-term relationship, and the accompanying higher level of identification with the company, would not mitigate consumers' negative reaction to a company's behavior if it went "beyond the zone of tolerance". To test this hypothesis, we compared the reactions of veteran members versus newer members (became a member one year prior or less) to the two hypothetical scenarios (i.e. loss of shared values, and lapse in ethical integrity). Analysis of the data showed that the longer-term relationship of "veteran" customers did not serve to attenuate the negative impact of either of the two hypothetical situations. Specifically, veteran members, who were significantly more likely to renew their membership than the newer members in our sample at the outset, did not differ significantly from newer members in their likelihood to renew in response to the two hypothetical situations, i.e. when shared values were diminished or when the organizations' ethical integrity was 
compromised. Apparently, even a longer-term relationship with the organization, and an initially higher intent to continue the relationship, does not serve to cushion the catastrophic blow to customer-company identification when company actions are perceived to reach "beyond the zone of tolerance".

Age also did not serve as a distinguishing factor among the reactions of customers. That is, when the age groups were collapsed into two categories, one consisting of the four younger age groups and the other, the four older age groups, no differences in their likelihood to renew their membership emerged between the two age categories in their baseline likelihood to renew, nor in their likelihood to renew under the two hypothetical conditions tested.

\section{DISCUSSION}

The results of this study lend support to the proposal that the positive consequences of strong consumercompany identification do, indeed, have their limits. That is, when negative information about a company's identityrelated behavior breaches the so-called "zone of tolerance" (proposed by Bhattacharya and Sen, 2003), the fallout of support from highly identified consumers will be severe. Strongly identified consumers were shown here to react with a significant increase in their intent to dissolve their relationship with the company when exposed to rather negative identity-related information about the company. Of the two types of severely negative identity-related information tested here - a diminishment of shared values and a lapse in ethical integrity - the latter elicited a significantly stronger intention by consumers to dissolve their relationship with the company.

The results of this study strongly demonstrate the crucial role that an organization's perceived values and ethical integrity can play in destabilizing or dissolving a strong customer-company identification. We examined a customer base (members of a public radio station) that showed an extremely high level of satisfaction and high likelihood to continue their relationship with the company. By any measure, this group's relationship with the company was very strong and positive. While a company or organization should not take its customers for granted, these radio station members did not initially appear to be at risk for leaving the franchise.

The obvious question, then, is "How hard is it to erode a relationship that is so strongly entrenched in the hearts and minds of the customers and that serves to satisfy their self-definitional needs?" Our study suggests that it is not very hard at all. In this study, we found that when consumers who are highly satisfied and strongly identified with a company experience a diminished sense of shared values with the company that goes "beyond a zone of tolerance", then a devastating loss of these highly identified consumers would result. A severe challenge to their sense of shared values appears to result in customers' withdrawal of their identification with the company and a much-increased intention to dissolve their relationship with the company.

We also found that the enormous negative impact on the customer-company identification would be even greater if a company should become tainted by a breach of ethical integrity (in this case, merely through association, by accepting financial support from an unethical underwriter). This effect can be understood as the company's deep betrayal of its identity authenticity. Customers' severe reaction to the hypothetical situation, as evidenced by the very steep decline in their intention to renew their membership, underscores the importance of the trust implied in the relationship between the company and those customers who have chosen to become strongly identified with it. It is important to note that while association with ethical entities that espouse dissimilar values does not have quite as strong a negative impact on the customer-company relationship as does association with unethical behavior, both behaviors appear to significantly and dramatically destabilize the basic bond between the two parties.

Our results also provided evidence for our proposed extension of Bhattacharya and Sen's (2003) conceptual framework that addresses the question of relationship dissolution as a function of the duration of the relationship. As hypothesized, the duration of the customer-company relationship was not found to mitigate the damaging effects of a diminishment of shared values or of a breach of ethical integrity - even though longer-term membership was associated with higher initial intentions to renew membership. In our study, the longer-term relationship appeared to be just as vulnerable to "stormy weather" as the newer relationship, even though trust and commitment had been experienced over a longer period of time in the former group. Apparently, a sense of betrayal of identity 
authenticity due to a loss of shared values with the company or a lapse in ethical integrity presents particularly severe challenges to customer-company identification that go beyond the "zone of tolerance", even if the identification had been an especially strong one held over a long period of time.

\section{AUTHOR INFORMATION}

Susan G. Rozensher is Associate Professor of Marketing at Iona College, New Rochelle, New York. She received her Ph.D. from Columbia University and her teaching and research interests include customer loyalty, customercompany identification, marketing research, and marketing education.

P. Everett Fergenson is Professor of Marketing at Iona College in New Rochelle, New York. He received his $\mathrm{Ph} . D$. from the University of Massachusetts at Amherst, and his teaching and research interests include business ethics, consumer psychology, sports marketing, and marketing education.

\section{REFERENCES}

1. Ahearne, M., Bhattacharya, C., and Gruen, T. (2005), "Antecedents and Consequences of CustomerCompany Identification: Explanding the Role of Relationship Marketing", Journal of Applied Psychology, Vol. 90 No. 3, pp. 574-585.

2. Ahluwalia, R. Unnava, H.R. and Brunkrant, R.E. (1999), "Towards understanding the value of a loyal customer: An information-processing perspective”, Marketing Science Institute, Report No. 99-116, Cambridge, MA.

3. Ashforth, B. E. and Mael, F. (1989), "Social identity theory and organization", Academy of Management Review, Vol. 14 No. 1, pp. 20-39.

4. Ball, D., Coelho, P. and Machas, A. (2004), "The role of communication and trust in explaining customer loyalty: An extension to the ECSI model", European Journal of Marketing, Vol. 38 No. 9/10, pp. 12721293.

5. Bellizzi, J. and Bristol, T. (2004), "An assessment of supermarket loyalty cards in one major US market", Journal of Consumer Marketing, Vol. 21 No.2/3, pp. 144-154.

6. Bendall-Lyon, D. and Powers, T. (2002), "The impact of gender differences on change in satisfaction over time", Journal of Consumer Marketing, Vol. 19 No. 1, pp. 12-21.

7. Bennett, R. and Rundle-Tiele, S. (2004), "Customer satisfaction should not be the only goal", Journal of Services Marketing, Vol. 18 No. 6/7, pp. 514-523.

8. Bergami, M. and Bagozzi, R(2000)., "Self categorization, affective commitment and group self-esteem as distinct aspects of social identity in the organization", British Journal of Social Psychology, Vol. 39 No. 4, pp. 555-77.

9. $\quad$ Berry, L. L. (1983) "Relationship Marketing”, in Berry, L., Shostack, G.L., and Upah, G. D. (Eds). Emerging Perspectives on Service Marketing, American Marketing Association, Chicago, IL, pp. 25-28.

10. Bhattacharya, C.B., Rao, H. and Glynn, M. A.(1995), "Understanding the bond of identification: An investigation of its correlates among art museum members", Journal of Marketing, Vol. 59 No. 4, pp. 4657.

11. Bhattacharya, C. B. and Sen, S. (2003), "Consumer-company identification: A framework for understanding consumers' relationships with companies”, Journal of Marketing, Vol. 67 No. 2, pp. 76-89.

12. Brewer, M. B. (1991), "The social self: On being the same and different at the same time", Personality and Social Psychology Bulletin, Vol. 17 No. 5, pp. 475-82.

13. Chaudhuri, A. and Holbrook, M. (2001), "The chain of effects from brand trust and brand effect to brand performance: the role of brand loyalty", Journal of Marketing, Vol. 65 No. 2, pp.81-93.

14. De Wulf, K., Schoroder, G. and Lacobucci, D. (2001), "Investments in consumer relationship: a cross country and cross industry exploration", Journal of Marketing, Vol. 65 No. 4, pp.33-50.

15. Dick, A. and Basu, K. (1994). "Consumer loyalty: toward an integrated conceptual framework", Journal of the Academy of Marketing Science, Vol. 22 No. 2, pp.99-113.

16. DiMaggio, P. J. and Ostrower, F. (1990). "Participation in the arts by black and white Americans", Social Forces, Vol. 68, pp. 753-758. 
17. Divett, M., Crittendon, N. and Henderson, R. (2003), “Actively influencing consumer loyalty”, Journal of Consumer Marketing, Vol. 20 No. 2/3, pp. 109-127.

18. Dowling, G. and Uncles, M. (1997), "Do customer loyalty programs really work?" Sloan Management Review, Vol. 38 (Summer), pp. 71-82.

19. Dutton, J. E., Dukerich, J. M. and Harquail, C. V. (1994), Organizational images and member identification," Administrative Science Quarterly, Vol. 39 No. 2, pp. 239-63.

20. Kramer, R. M. (1991), "Intergroup relations and organizational dilemmas: The role of categorization processes", Research in Organizational Behavior, Vol. 13, pp. 191-207.

21. Fajer, M.T. and Schouten, J.W. (1995), "Breakdown and dissolution of person-brand relationships", Advances in Consumer Research, Vol. 22, pp. 663-667.

22. Fournier, S. (1998), "Consumers and their brands: Developing relationship theory in consumer research", Journal of Consumer Research, Vol. 24 No. 4, pp.343-373.

23. Gundlach, G. Achrol, R. and Mentzer, J. (1995), "The structure of commitment in exchange", Journal of Marketing, Vol. 59 No. 1, pp. 78-92.

24. Kotler, P., (1997), Marketing Management: Analysis, Planning, Implementation and Control, $9^{\text {th }}$ ed. Upper Saddle River, NJ: Prentice Hall.

25. Krosnick, J.A and Petty, R.E. (1995) “Attitude strength: An overview”, in Petty, R. E. and Krosnick, J.A. (Eds.), Attitude Strength: Antecedents and Consequences (Mahwah, NJ: Lawrence Erlbaum, pp. 1-24.

26. Lewis, M. (2004), "The influence of loyalty programs and short-term promotions on customer retention", Journal of Marketing Research, Vol. 41 No. 3, pp. 281-292.

27. Mael, F. and Ashforth, B. E. (1992), "Alumni and their alma mater: A partial test of the reformulated model of organizational identification”, Journal of Organizational Behavior, Vol. 13 No. 2, pp. 103-23.

28. Markus, H. R. and Wurf, E. (1987), “The dynamic self-concept: A social-psychological perspective," Annual Review of Psychology, Vol. 38, pp. 299-337.

29. McConnell, B. and Huba, J. (2003). Creating Customer Evangelists, Dearborn Financial Publishing, Chicago, IL.

30. Morgan, R. M. and Hunt, S. D. (1994) "The commitment-trust theory of relationship marketing”, Journal of Marketing, Vol. 58 No. 3, pp.20-38.

31. Oliver, R. (1997), Satisfaction: A Behavioral Perspective on the Consumer, Irwin/McGraw-Hill, Boston, MA.

32. Perrin-Martinenq, D. (2004), "The role of brand detachment on the dissolution of the relationship between the consumer and the brand", Journal of Marketing Management, Vol. 20 No. 9/10, pp. 1001-1022.

33. Pratt, M. G. (1998), "To be or not to be: Central questions in organizational identification", in Whetton, David A. and Godfrey, Paul C. (Eds) Identity in Organizations: Building Theory Through Conversations, Thousands Oaks, CA: Sage Publications, pp. 171-207.

34. Rees, P. and Gardner, H. (2003) "Best value, partnerships and relationship marketing in local government", International Journal of NonProfit and Voluntary Sector Marketing, Vol. 8 No. 2, pp. 143-152.

35. Reichheld, F. F. (1993). "Loyalty based management", Harvard Business Review, Vol. 71 No. 2, pp. 6473.

36. Reichheld, F. F. and Sasser, E. W. (1990). "Zero defections: Quality comes to services", Harvard Business Review, Vol. 68 No. 5, pp. 105-116.

37. Reichheld, F. and Teal, T. (1996), The Loyalty Effect: the Hidden Force Behind Growth, Profits, and Lasting Value, Harvard Business Press, Cambridge, MA.

38. Rowley, J. and Dawes, J. (2000), "Disloyalty: A closer look at non-loyals", Journal of Consumer Marketing, Vol. 17 No. 6, pp. 538.

39. Scott, S. G. and Lane, V. R. (2000), "A stakeholder approach to organizational identity," Academy of Management Review, Vol. 25 No. 1, 43-62.

40. Shankar, V., Smith, A. K. and Rangaswamy, A. (2003), "Customer satisfaction and loyalty in online and offline environments", International Journal of Research in Marketing, Vol. 20, pp.153-175.

41. Sharp, B. and Sharp, A. (1997), "Loyalty programs and their impact on repeat-purchase loyalty patterns", International Journal of Research in Marketing, Vol. 14 No. 5, pp.473-486.

42. Shemwell, D. Cronin, J.J., and Bullard, W. R. (1994), "Relational exchange in services: An empirical investigation", International Journal of Service Industry Management, Vol. 5 No. 3, pp. 57-68. 
43. Trajfel, H. and Turner, J. C. (1985), "The social identity theory of intergroup behavior," in Worchell, S. and Austin, W. (Eds), Psychology of Intergroup Relations, Chicago: Nelson-Hall, pp. 6-24.

44. Uncles, M., Dowling, G. and Hammond, K. (2003), "Customer loyalty and customer loyalty programs", Journal of Consumer Marketing, Vol. 20 No. 4/5, pp. 294-316.

45. Woodruff, R. B. (1997), "Customer value: The next source for competitive advantage", Journal of the Academy of Marketing Science, Vol. 25 No. 2, pp. 139-153.

46. Zeithaml, V. (2000), "Service quality, profitability and the economic worth of customers: what we know and what we need to learn", Journal of the Academy of Marketing Science, Vol. 28 No. 1, pp. 67-85.

47. Zeithaml, V., Rust, R. and Lemon, K. (2001), "The customer pyramid: creating and serving profitable customers", California Management Review, Vol. 43 No. 4, pp. 118-42.

\section{NOTES}


NOTES 